Ambiente \& Água - An Interdisciplinary Journal of Applied Science
ISSN 1980-993X - doi:10.4136/1980-993X
www.ambi-agua.net
E-mail: ambi.agua@gmail.com

\title{
Drinking water quality in schools of the Santarém region, Amazon, Brazil, and health implications for school children
}

\author{
ARTICLES doi:10.4136/ambi-agua.2218
}

Received: 29 Nov. 2017; Accepted: 23 Sep. 2018

\author{
Marina Smidt Celere Meschede ${ }^{1 *}$; Bernardino Ribeiro Figueiredo² \\ Renato Igor da silva Alves³; Susana Inés Segura-Muñoz ${ }^{3}$ \\ ${ }^{1}$ Universidade Federal do Oeste do Pará (UFOPA), Santarém, PA, Brasil \\ Instituto de Saúde Coletiva (ISCO). E-mail: marcelere@ yahoo.com.br \\ ${ }^{2}$ Universidade Estadual de Campinas (UNICAMP), Campinas, SP, Brasil \\ Instituto de Geociências (IG). E-mail: berna@ige.unicamp.br \\ ${ }^{3}$ Universidade de São Paulo (USP), Ribeirão Preto, SP, Brasil \\ Escola de Enfermagem de Ribeirão Preto (EERP). \\ Departamento de Enfermagem Materno-Infantil e Saúde Pública (DEMISP). \\ E-mail: renatobio_usp@yahoo.com.br, susis@eerp.usp.br \\ *Corresponding author
}

\begin{abstract}
The quality of drinking water and its health implications for school children were examined at schools in the Santarém region, Amazon, Brazil. In this region, the population is fully supplied by groundwater from the voluminous Alter do Chão aquifer. Drinking water samples from three schools in Santarem city and from one school at the rural Mojuí dos Campos town were subjected to microbiological and physicochemical compositional analyses. The health risk of human exposure to chemical compounds through water intake was also evaluated. The results indicated that most water samples were contaminated with total coliform and with E. coli, which could cause serious intestinal disorders for school children. Drinking water was acidic and most of the chemical element concentrations were within Brazilian water potability recommended levels. One exception was the high aluminium content in schools from Santarem served by shallower wells, suggesting that further epidemiological studies are necessary and the monitoring of exposed school children should not be discarded. Elevated nitrate concentrations were also noted in schools from Santarém with shallower wells, indicating lack of sanitation and the importance of periodic monitoring of drinking water to prevent adverse health effects. Quantification of human health risk indicated a hazard in schools served by shallower wells, with aluminium as the main pollutant, followed by nitrate. The results showed that most drinking water quality parameters are in accordance with Brazilian legislation. However, microbiological contamination, water acidity, aluminium and nitrate concentrations must be taken into consideration for local governments in order to prevent related diseases among school children.
\end{abstract}

Keywords: Amazon, drinking water, groundwater, health, pollution. 


\section{Qualidade da água de consumo em escolas na região de Santarém, Amazônia, Brasil e implicações para saúde dos escolares}

\section{RESUMO}

Qualidade da água de consumo e implicações em saúde de escolares foram avaliadas em escolas na região de Santarém, Pará, Amazônia. Nessa região, a população é abastecida totalmente por água subterrânea do volumoso aquífero Alter do Chão. Amostras de água de consumo de três escolas na cidade de Santarém e uma escola no município rural de Mojuí dos Campos foram submetidas a análises microbiológicas e de composição físico química. O risco à saúde por meio da exposição a contaminantes químicos pela ingestão da água, também, foi avaliado. Os resultados indicaram que a maior parte das amostras estiveram contaminadas por coliformes totais e E.coli, o que poderá ocasionar distúrbios intestinais importantes nos escolares. A água é ácida e as concentrações dos elementos químicos estão de acordo com os níveis recomendados pela legislação brasileira. Uma exceção foi observada para o alumínio, que apresentou concentrações superiores ao recomendado na água das escolas de Santarém com poços mais rasos, sugerindo que novos estudos epidemiológicos devam ser realizados e o monitoramento de crianças expostas não deverá ser descartado. Concentrações elevadas de nitrato também foram encontradas na água das escolas de Santarém com poços mais rasos, indicando deficiências sanitárias e a importância do seu monitoramento visando evitar efeitos em saúde. A avaliação quantitativa de risco em saúde evidenciou perigo somente nas escolas com poços mais rasos, sendo que o principal contribuinte foi o alumínio, seguido do nitrato. Os resultados mostram que a maioria dos parâmetros de qualidade da água das escolas estão de acordo com os limites recomendados pela legislação brasileira, entretanto, a contaminação microbiológica, a acidez e as concentrações elevadas de alumínio e nitrato na água devem ser consideradas prioridades visando a prevenção de doenças relacionadas com consumo de água pelos escolares.

Palavras-chave: água de consumo, água subterrânea, Amazônia, saúde, poluição.

\section{INTRODUCTION}

Water is essential to sustain life, and a satisfactory water supply must be available to the human population. According to the World Health Organization (WHO), in 2017, access to safe drinking water can result in tangible benefits to health (WHO, 2017). Safety of the water supply is key to public health, especially for children, who generally require greater protection. School children can spend five to eight hours a day in public elementary schools in Brazil. In this sense, it is essential that this communal space presents favourable environmental conditions to ensure good health practices and quality of life for children.

Adequate quality of drinking water is a human right (WHO, 2017). Unfortunately, the supply of safe drinking water has been compromised by the absence of adequate sanitary infrastructure in some regions of developing countries like Brazil, where this vital resource is vulnerable to pollution. In the case of groundwater supply, over the past 20 years it has become increasingly apparent that groundwater sources are being contaminated by hazardous microbiological agents and chemicals derived from a variety of social, economic and urban activities; therefore groundwater protection has become essential for governmental agencies (Palamuleni and Akoth, 2015; Llopis-González et al., 2014).

Groundwater is an important source of drinking water and often requires little or no treatment. Nevertheless, diseases caused by contaminated groundwater consumption are reported from countries at all levels of economic development (WHO, 2006). In general, 
groundwater has good microbiological quality, but may become rapidly polluted if protective actions are not implemented and well maintained. Some studies highlight microbiological contamination due to the proximity of septic tanks to artesian wells in countries with precarious basic sanitation infrastructure (Dahunsi et al., 2014; Mendes et al., 2017). Fecal-derived pathogens are the principal concerns in setting health-based targets for microbial safety and diarrhea is the most common disease in school children that is associated with water contaminated by pathogens through the fecal-oral route (WHO, 2006). The control of the microbial quality of drinking water should be the first priority in all countries, given the immediate and potentially devastating consequences of waterborne infectious disease.

The health concerns associated with chemical constituents of drinking water differ from those associated with microbial contamination and arise primarily from the ability of chemicals to cause adverse health effects after prolonged periods of exposure, as evidenced by Kim et al. (2016). There are many inorganic and organic compounds that naturally occur in groundwater which may originate from the rocks and soil percolated by the water. However, chemicals from anthropogenic sources (i.e., urban or agricultural activities) can reach groundwater from diverse sources arising from the use and disposal of materials and products containing toxic elements in high concentrations, such as trace elements and nitrates (WHO, 2017).

Assessing groundwater quality and the risk for human health has become an important task in public health concerns. Studies of the quality of drinking water collected by wells have been developed worldwide, and are of great importance (Majumdar and Gupta, 2000; Nalbantcilar and Pinarkara, 2016; Lapworth et al., 2018). In the Santarém region, there is a lack of research involving groundwater quality and health. Some studies (Azevedo, 2006; Aguiar et al., 2014) have been carried out investigating surface water quality in the Amazon region and, in general, the implications for ecosystems, such as the effects on fish development and other living aquatic organisms. For these reasons, in this study we investigated the quality of drinking groundwater in four schools in the Amazon region, three located in an urban area, Santarém city, and one in a rural area, Mojuí dos Campos, during two seasons (dry and rainy). We compared the results with reference values from Brazilian legislation Ordinance 2914 (Brasil, 2011), which provides the standards for drinking water in Brazil based on the guidelines of the WHO. The health risk for children associated with ingestion of chemical compounds through drinking water was also quantified in schools, following the United States Environmental Protection Agency (USEPA) guidelines (USEPA, 1989; 1996).

\section{MATERIALS AND METHODS}

\subsection{Study area}

The study area is located in the Santarém region, in the west of Pará State, in the Brazilian Amazon. The region of Santarém includes the urbanized city of Santarém and the rural Mojuí dos Campos town, $30 \mathrm{~km}$ southeast of Santarém city (Figure 1). This region has a seasonal climate with two distinct periods (i) dry season (July to November) and (ii) rainy season (December to May), with June considered a transition month (Gomes et al., 2016). The climate in the Santarém region is tropical humid, and is classified as Am3 in the Köppen climate classification system (Köppen, 1936). In the last two years, according to the Brazilian National Institute of Meteorology (INMET), 95\% of recorded values of temperature were in the range of $32.7^{\circ} \mathrm{C}-22.5^{\circ} \mathrm{C}$ in the dry season and $31.2^{\circ} \mathrm{C}-22.3^{\circ} \mathrm{C}$ in the rainy season. In 2016 , the total precipitation and average relative humidity in the dry season were $371.5 \mathrm{~mm}$ and $84.6 \%$, and in the rainy season these were $986.0 \mathrm{~mm}$ and $87.4 \%$, respectively (INMET, 2017). 


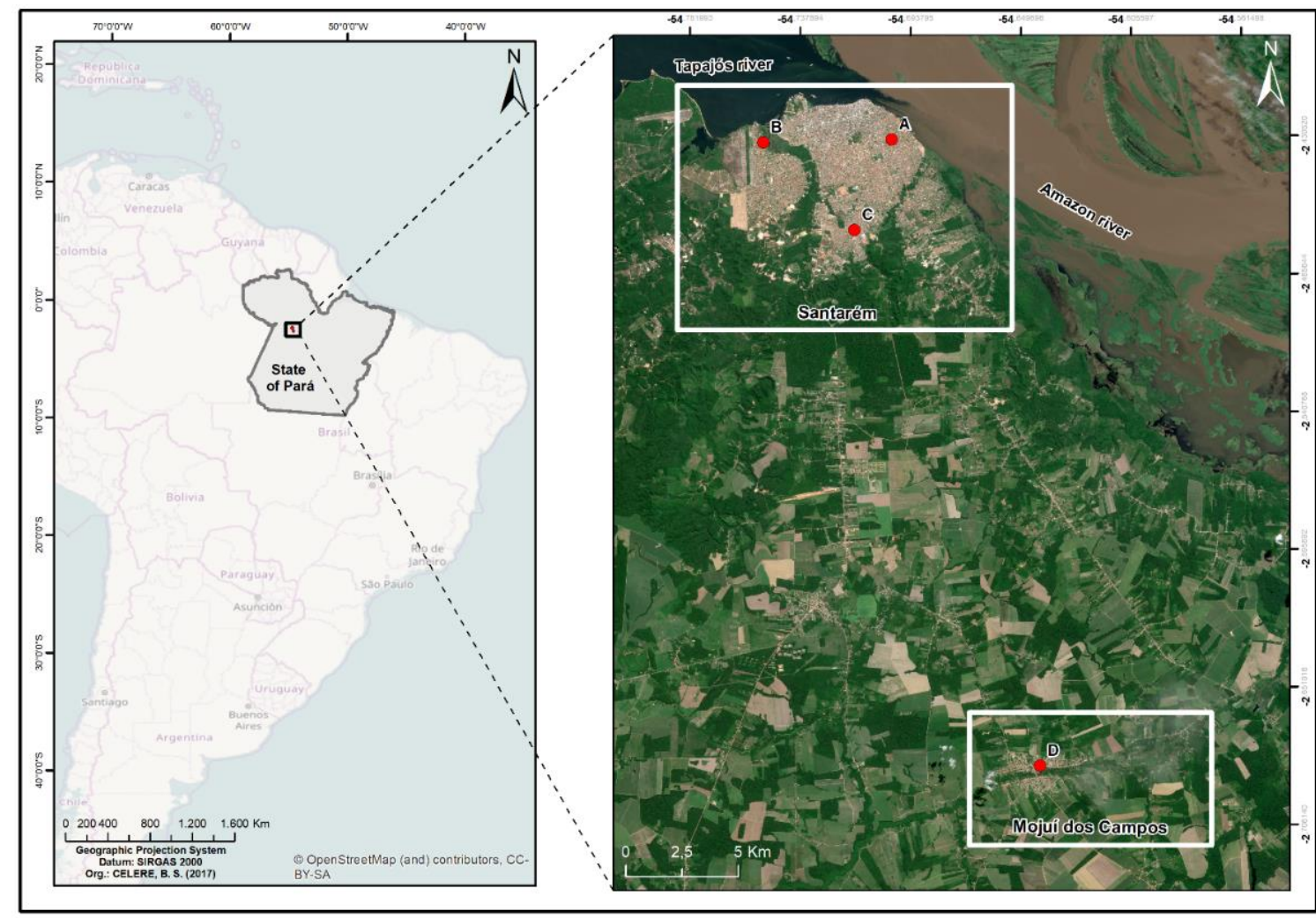

Figure 1. Location map of the State of Pará and Santarém region indicating the Schools A, B and C in Santarém and the Sschool D at Mojuí dos Campos, State of Pará, Amazon, Brazil.

The city of Santarém had an estimated 294.447 inhabitants in 2016 according to the Brazilian Institute of Geography and Statistics (IBGE, 2016), and is the second most important urban region in the State of Pará, with economic activity based on local commerce, and it is located at the intersection of the Tapajos and Amazonas Rivers (Figure 1). These two rivers are important routes for regional transport; however, surface water is not used for human consumption. The Sanitation Company of Pará (COSANPA) and the Municipality of Santarém distribute drinking water in Santarém. COSANPA takes advantage of its own deep-water wells (> $250 \mathrm{~m}$ ) that intercept the Alter do Chão aquifer and distributes water to $61 \%$ of the population; of these, $49 \%$ receive chlorinated water, whereas $12 \%$ of the population is not served by treated and disinfected water (COSANPA, 2013). The voluminous Alter do Chão aquifer is the major groundwater supply for most of the State of Pará (Tancredi, 1996). The Municipality of Santarém captures drinking water from shallower wells at 18 to $30 \mathrm{~m}$ deep. Households and other areas that are not served by either of these two water systems use groundwater from private shallow wells. According to the Sanitation Ranking published by the Trata Brazil Institute (2016), Santarém is among the ten municipalities in Brazil with the poorest drinking water treatment system.

The town of Mojuí dos Campos has 15.548 inhabitants (IBGE, 2016), and the main economic activity is the agricultural cultivation of soybeans, corn and black pepper. Agriculture plays a key role in supporting the rural population of the area. At Mojuí dos Campos, there is an important main water microsystem which captures water for human consumption from the Alter do Chão aquifer at a depth of $202 \mathrm{~m}$ without treatment and water disinfection.

\subsection{Overview of schools and water sampling}

A total of 36 drinking groundwater samples were collected at three elementary schools in Santarém (denominated in this study as Schools A, B and C) and at one school at Mojuí dos 
Campos (denominated in this study as School D) (Figure 1). An overview of the characteristics of these schools is shown in Table 1. The water at the schools is used for food preparation, washing of household utensils, in the toilets and as drinking water by school children and employees. The supply of drinking water after its underground capture is provided by tanks (water tanks) with a capacity of up to $1.500 \mathrm{~L}$, which are located inside the schools and made of polyethylene and fitted with a lid. Water was sampled from a drinking fountain over a period of three months (one sampling day in February, March and April) in the rainy season and in another three months (one sampling day in September, October and November) in the dry season, between 2015 and 2017. Immediately preceding water sampling the drinking fountains were cleaned with $70 \%$ alcohol and then tapped and allowed to drain for one to two minutes, following specifications established by the Brazilian Ministry of Health - National Health Foundation of Brazil (FUNASA, 2006). The volumes of the collected samples were $100 \mathrm{~mL}$ for the bacteriological analyses, $1 \mathrm{~L}$ for the parasitological analyses, $200 \mathrm{~mL}$ for the physicochemical parameters, and $100 \mathrm{~mL}$ for chemical analyses. After collection, the samples were conserved in a cold thermal box $\left(4^{\circ} \mathrm{C}\right)$ until the analyses were conducted.

Table 1. Overview of schools in Santarém (A, B and C) and in Mojuí dos Campos (D) in the western region of the State of Pará, Amazon, Brazil.

\begin{tabular}{|c|c|c|c|c|}
\hline Characteristics & School A & School B & School C & School D \\
\hline Location & Santarém city & Santarém city & Santarém city & Mojuí dos Campos \\
\hline $\begin{array}{l}\text { Number of } \\
\text { students in } \\
2017\end{array}$ & 823 & 306 & 1069 & 376 \\
\hline $\begin{array}{l}\text { Drinking water } \\
\text { source }\end{array}$ & $\begin{array}{c}\text { Groundwater } \\
\text { (30 m deep) - private } \\
\text { well }\end{array}$ & $\begin{array}{l}\text { Groundwater } \\
\text { (200 m deep) - } \\
\text { COSANPA }\end{array}$ & $\begin{array}{l}\text { Groundwater } \\
\text { (18 m deep) } \\
\text { - private well }\end{array}$ & $\begin{array}{l}\text { Groundwater } \\
\text { (202 m deep) municipal } \\
\text { microsystem }\end{array}$ \\
\hline $\begin{array}{l}\text { Water storage } \\
\text { after } \\
\text { underground } \\
\text { collection }\end{array}$ & Water tank & Water tank & Water tank & Water tank \\
\hline $\begin{array}{l}\text { Sewage } \\
\text { treatment }\end{array}$ & Septic tank & Septic tank & Septic tank & Septic tank \\
\hline $\begin{array}{l}\text { Distance of } \\
\text { septic tank of } \\
\text { school to } \\
\text { groundwater } \\
\text { well }\end{array}$ & Approximately $15 \mathrm{~m}$ & More than $50 \mathrm{~m}$ & $\begin{array}{l}\text { Approximately } \\
15 \mathrm{~m}\end{array}$ & More than $50 \mathrm{~m}$ \\
\hline
\end{tabular}

\subsection{Water analyses}

The drinking water samples from the schools were analysed for microbiological characteristics (total coliform, E.coli, heterotrophic bacteria and parasites), physicochemical parameters $(\mathrm{pH}$, turbidity, conductivity and alkalinity) and chemical composition (anions and trace elements).

The microbiological analyses for total coliforms, E. coli and heterotrophic bacteria were carried out using a vacuum pump and the method of membrane filters following standard methods of FUNASA (2006), which consists of filtration of $100 \mathrm{ml}$ of the water sample through a sterile membrane with $47 \mathrm{~mm}$ in diameter and a porosity of $0.45 \mu \mathrm{m}$. The membranes were then placed in Petri plates with a Rapid HiColiform Agar (Himedia ${ }^{\circledR}$ ) culture media for growth of total coliforms and E.coli. Petri plates were incubated at $35^{\circ} \mathrm{C}$ for $24 \pm 2$ hours in order to count Colony Forming Units (CFU) of total coliforms; after incubation, the colonies that grew 
with blue-greenish coloration were considered as total coliforms. The Petri plates were incubated at $44^{\circ} \mathrm{C}$ for $24 \pm 2$ hours for $E$. coli counting and after incubation, the Petri plates were exposed to ultraviolet light $(366 \mathrm{~nm}, 6 \mathrm{~W})$ at a distance of 6 to $8 \mathrm{~cm}$ in a dark environment. A positive result was considered for E.coli when colonies in the fluorescent staining were detected. For the reading of heterotrophic bacteria, the result was considered positive when there was CFU present on the membrane after the pre-established conditions of incubation. Heterotrophic bacteria Petri plates were incubated for $35^{\circ} \mathrm{C}$ for $48 \pm 3$ hours with de media Plate Count Agar (Himedia ${ }^{\circledR}$ ) for counting the colonies. The counting of heterotrophic bacteria includes the entire group of microorganisms that is capable of growing in a nutrient-rich solid medium agar.

Parasitological analysis was performed using the spontaneous sedimentation method, for a determination of eggs, cysts and larvae of helminths and protozoa. For this analysis, $1 \mathrm{~L}$ of the water sample was arranged in a sedimentation chalice, where it remained for a period of 24 hours. Afterwards, $1 \mathrm{ml}$ of the sediment material was deposited on a slide and stained with a drop of lugol solution (Neves, 2005; Ferreira et al., 2008; Julião, 2011). The material was then analysed under an optical microscope NIKON Model E200.

The $\mathrm{pH}$ of the water was measured by the potentiometric method using a portable $\mathrm{pH}$ meter, Model HI 991003 (Hanna ${ }^{\circledR}$ ), at a temperature of $25-30^{\circ} \mathrm{C}$, and water turbidity and conductivity were measured with the same equipment. Alkalinity was determined by titration measuring the amount of sulphuric acid used, and the calculation indicated the amount of carbonate and bicarbonate ions involved in the reaction expressed as mg.L of $\mathrm{CaCO}_{3}$ (Brazil, 2006).

Samples intended for chemical composition analyses were filtered through a $0.2 \mu \mathrm{m}$ syringe filter and kept cooled $\left(4^{\circ} \mathrm{C}\right)$ until analysis. Additionally, samples intended for traceelement analysis by Inductively Coupled Plasma Mass Spectrometer (ICP-MS) were preserved with two drops of concentrated $\mathrm{HNO}_{3}$ at a $\mathrm{pH}$ of less than 2 .

The anion contents in water were analysed by Ion Chromatography in a Thermo Scientific Dionex ICS-5000 spectrophotometer. All the samples were analysed for fluoride $\left(\mathrm{F}^{-}\right)$, chloride $\left(\mathrm{Cl}^{-}\right)$, nitrite $\left(\mathrm{N}^{-} \mathrm{NO}_{2}{ }^{-}\right)$, nitrate $\left(\mathrm{N}-\mathrm{NO}_{3}{ }^{-}\right)$, sulphate $\left(\mathrm{SO}_{4}{ }^{2-}\right)$, bromide $\left(\mathrm{Br}^{-}\right)$and phosphate $\left(\mathrm{PO}_{4}{ }^{3-}\right)$. For the anions, the following components were used: an IonPaC AS19 Capillary Column $(0.4 \times 250 \mathrm{~mm})$ in combination with the AG19 Guard Column $(0.4$ x $50 \mathrm{~mm})$, Anion Capillary Electrolytic Suppressor (ACES ${ }^{\mathrm{TM}}$ 300) and Eluent Generator Cartridges for the generation of potassium hydroxide $\left(\mathrm{KOH}^{-}\right)$with concentrations between 2 and $50 \mathrm{mmol} \mathrm{L} \mathrm{L}^{-1}$. The runs lasted $30 \mathrm{~min}$ with a flow of $0.010 \mathrm{~mL} \mathrm{~min}^{-1}$ with the following concentrations' slope: 0-10 min (2-10 mmol L-1 $)$; 10-20 min (10-45 mmol L-1) and 21.1-30 min (2-2 $\left.\mathrm{mmol} \mathrm{L}^{-1}\right)$. For cations, the components were as follows: IonPac CS12A Capillary Column (2 x $250 \mathrm{~mm})$ in combination with the CG12A Guard Column (2 x $50 \mathrm{~mm})$, Cations Capillary Electrolytic Suppressor (CCES ${ }^{\mathrm{TM}}$ 300) and Eluent Generator Cartridges (EGC) for the generation of methanesulfonic acid (MSA) at a concentration of $20 \mathrm{mmol} \mathrm{L}^{-1}$ and a flow $0.25 \mathrm{~mL} \mathrm{~min}^{-1}$ throughout the 17 minutes of the run. For both determinations, the injection was made by the Automatic Sampling System (Dionex AS-AP) with a high-performance conductivity detector. Data were analyzed with the Chromeleon 6.8 software. For the equipment calibration, analytical curves were constructed for each of the ionic species, obtaining seven concentration points (in triplicate) for each curve at the following concentrations: $0.2 ; 0.4 ; 0.6 ; 0.8 ; 1.0 ; 2.0$ and $3.0 \mathrm{mg}$ $\mathrm{L}^{-1}$. The detection limits in $\mathrm{mg} \mathrm{L}^{-1}$ were estimated to be 0.001 for $\mathrm{F}^{-} ; 0.015$ for $\mathrm{Cl}^{-}$and $\mathrm{PO}_{4}{ }^{3-} ; 0.005$ for $\mathrm{NO}_{2}{ }^{-}$and $\mathrm{Br}^{-} ; 0.003$ for $\mathrm{NO}_{3}{ }^{-}$and 0.010 for $\mathrm{SO}_{4}{ }^{2-}$.

The concentrations of the 57 trace elements were determined in all water samples by ICPMS equipped with collision cell technology (CCT) (Xseries II Thermo Scientific), but only 16 elements were quantified in this study: aluminium (Al); arsenic (As), boron (B), barium (Ba), 
calcium $(\mathrm{Ca})$, cadmium $(\mathrm{Cd})$, chromium $(\mathrm{Cr})$, copper $(\mathrm{Cu})$, iron $(\mathrm{Fe})$, potassium $(\mathrm{K})$, magnesium $(\mathrm{Mg})$, manganese $(\mathrm{Mn})$, sodium $(\mathrm{Na})$, nickel $(\mathrm{Ni})$, lead $(\mathrm{Pb})$ and zinc $(\mathrm{Zn})$. For quality control, all analyses were performed in triplicate and quality control of the measurements was carried out by the analysis of the reference material: River Water Reference Material for Trace Metals (SLRS-5). The detection limits in $\mathrm{ng} \mathrm{mL}^{-1}$ were estimated to be 0.4 for $\mathrm{Al}, 0.005$ for As, 1.2 for B, 0.009 for $\mathrm{Ba}, 9.3$ for $\mathrm{Ca}, 0.004$ for $\mathrm{Cd}, 0.01$ for $\mathrm{Cr}, 0.05$ for $\mathrm{Cu}$, 29 for $\mathrm{Fe}, 47$ for K, 0.2 for $\mathrm{Mg}, 0.03$ for $\mathrm{Mn}, 2$ for $\mathrm{Na}, 0.04$ for Ni, 0.002 for $\mathrm{Pb}$ and 0.1 for $\mathrm{Zn}$.

\subsection{Data analysis}

Element concentrations were examined by descriptive statistics and compared with the maximum values recommended by Brazilian Ordinance 2914 that provides guidelines for controlling and monitoring the quality of drinking water for human consumption in Brazil (Brazil, 2011).

USEPA guidelines were used to quantify risk for human health considering the exposure through ingestion of groundwater in the schools (USEPA 1989; 1996). Human health risk assessment has become a widely applied methodology to quantify the risks derived from exposure to environmental pollutants (Turdi and Yang, 2016). The health risks include noncarcinogenic and carcinogenic agents in drinking water for school children.

The non-carcinogenic risks were assessed by estimating the Hazard Quotient (HQ) and Hazard Index (HI) for each school during six months. The HQ was calculated as the quotient between the environmental Daily Exposure (DE) dose and the Reference Dose (RfD), which was obtained from the Integrated Risk Information System (IRIS) in mg.Kg.day (USEPA, 2014). The non-carcinogenic risk was calculated for chemicals that had their reference doses established by IRIS using the following Equation 1:

$D E=C * C o * E F * E D / B w * A T$

In the equation, $\mathrm{DE}$ is the daily exposure doses through oral intake ( $\mathrm{mg} \mathrm{Kg}-\mathrm{day}^{-1}$ ); $\mathrm{C}$ is the chemical concentration in water $\left(\mathrm{mg} \mathrm{L}^{-1}\right)$; Co is the volume of drinking water consumed by the children in one day (L); EF is exposure frequency in days; ED is the exposure duration in years; $\mathrm{Bw}$ is the average body weight in $\mathrm{kg}$ and $\mathrm{AT}$ is averaging time in days. Adopted values and description of the different parameters are shown in Table 2.

The Hazard Quotient (HQ) values were obtained for a number of elements (Al; As; Ba; B; $\mathrm{Cd} ; \mathrm{Cr} ; \mathrm{Cu} ; \mathrm{Mn} ; \mathrm{Ni} ; \mathrm{Zn}$ ) and for nitrate by the ratio between $\mathrm{DE}$ and their respective reference doses from IRIS (RfD). When the ratio exceeds the unit, it is characterized as a danger to human health, with the possibility of non-cancerous effects of human exposure to substances. Subsequently, the Hazard Index, defined as the total risk, was obtained by summing the HQ of each element. Values of the Hazard Index (HI) under unity are considered as safe.

\subsection{Ethical aspects}

The Research Ethics Committee of the State University of Pará (UEPA) approved this study in September 2015 with the register number 1.318.594. 
Table 2. Input data for calculating the non-carcinogenic risk for school children from drinking water in schools in Santarém (A, B and C) and in Mojuí dos Campos (D) in the Santarém region, Amazon, Brazil.

\begin{tabular}{|c|c|c|c|}
\hline Parameters & Values adopted & Unit & Reference data \\
\hline $\begin{array}{l}\text { Mean concentration of chemical } \\
\text { in drinking water }(C)\end{array}$ & Results of present study & $\mathrm{mg} \mathrm{L}^{-1}$ & Present study \\
\hline $\begin{array}{l}\text { Daily water consumption by } \\
\text { children }(\mathrm{Co})\end{array}$ & 1.26 & L day & USEPA (1996) \\
\hline Exposure frequency (EF) & 275 & days & USEPA (1996) \\
\hline Exposure duration (ED) & 06 & years & USEPA (1996) \\
\hline Body weight children (Bw) & 15 & $\mathrm{~kg}$ & USEPA (1996) \\
\hline $\begin{array}{l}\text { Averaging time for non- } \\
\text { carcinogenic exposure (ATnc) }\end{array}$ & ED x 275 (1650 days) & days & USEPA (1989) \\
\hline Reference Doses (RfD) from IRIS & $\begin{array}{c}\mathrm{Al}=0.018 \\
\mathrm{As}=0.0003 \\
\mathrm{Ba} \text { and } \mathrm{B}=0.2 \\
\mathrm{Cd}=0.0005 \\
\mathrm{Cr}=0.003 \\
\mathrm{Cu}=0.04 \\
\mathrm{Mn}=0.14 \\
\mathrm{Ni}=0.02 \\
\mathrm{Zn}=0.3 \\
\mathrm{~N} \text { - nitrate }=1.6\end{array}$ & mg kg day & USEPA (2014) \\
\hline
\end{tabular}

\section{RESULTS AND DISCUSSION}

\subsection{Microbiological contamination}

Table 3 shows the results of microbiological analyses of 36 water samples from schools corresponding to dry and rainy seasons and indicates the growth of Colony Forming Units (CFU) per $100 \mathrm{ml}$ water. The results showed the presence of heterotrophic bacteria in all samples whereas total coliforms were detected in 28 samples and E. coli in 16 samples. Cysts and parasites in water samples were not found. The concentrations of heterotrophic bacteria agree with Brazilian Ordinance 2914 (Brasil, 2011). The highest values were found in School A during the rainy season (240 to $1144 \mathrm{CFU} / 100 \mathrm{~mL}$ ) and in School C during the dry season (396 to $1694 \mathrm{CFU} / 100 \mathrm{~mL}$ ). These heterotrophic bacteria have no effects on human health, but are a good indicator of the quality of water (i.e., the lower the concentration of heterotrophic bacteria in drinking water the better its quality) (Brasil, 2011).

Detection of total coliforms in schools was accentuated during the rainy season with 17 positive samples compared to 11 samples in the dry season. Values of CFU varied widely between schools. The schools with shallower wells are more susceptible to the infiltration of soil contaminants that may increase during rainy periods. Some explanations can be raised for the growth of total coliforms in water samples. The proximity between wells and the septic tanks and the shallower depth of the wells in Schools A and C may favour the presence of coliforms and the higher value of CFU/100 mL. Septic tanks should be constructed in the lowest part of the area and at a minimum horizontal distance of approximately $16 \mathrm{~m}$ from the wells (USEPA, 2002). However, this criteria is not always followed at schools with shallower wells. Another explanation is the inadequate maintenance of water tanks in schools. The maintenance of these reservoirs in schools often does not follow a cleaning routine. 
Table 3. Microbiological analyses of drinking water samples from Schools A, B and C in Santarém and D in Mojuí dos Campos during the dry and rainy seasons, Santarém region, Amazon, Brazil, and the reference values from Brazilian Ordinance 2914.

\begin{tabular}{|c|c|c|c|c|c|c|c|c|c|}
\hline \multirow{2}{*}{$\begin{array}{l}\text { Microbiological } \\
\text { Parameters }\end{array}$} & \multicolumn{2}{|c|}{ School A } & \multicolumn{2}{|c|}{ School B } & \multicolumn{2}{|c|}{ School C } & \multicolumn{2}{|c|}{ School D } & \multirow[t]{2}{*}{$\begin{array}{l}\text { Reference value } \\
\text { Ordinance } 2914\end{array}$} \\
\hline & $\begin{array}{c}\text { Samples with } \\
\text { microbial } \\
\text { growth }\end{array}$ & $\begin{array}{l}\text { CFU/ } \\
100 \mathrm{~mL}\end{array}$ & $\begin{array}{l}\text { Samples } \\
\text { with } \\
\text { microbial } \\
\text { growth }\end{array}$ & $\begin{array}{c}\text { CFU/ } \\
100 \mathrm{~mL}\end{array}$ & $\begin{array}{l}\text { Samples with } \\
\text { microbial } \\
\text { growth }\end{array}$ & $\begin{array}{c}\text { CFU/ } \\
100 \mathrm{~mL}\end{array}$ & $\begin{array}{l}\text { Samples with } \\
\text { microbial } \\
\text { growth }\end{array}$ & $\begin{array}{c}\text { CFU/ } \\
100 \mathrm{~mL}\end{array}$ & \\
\hline Dry season & $n=6$ & & $n=3$ & & $n=6$ & & $n=3$ & & \\
\hline Heterotrophic bacteria & All samples & $73-724$ & All samples & $220-484$ & All samples & $396-1694$ & All samples & $132-643$ & $\begin{array}{c}<50.000 \\
\mathrm{CFU} / 100 \mathrm{~mL}\end{array}$ \\
\hline Total coliform & 3 samples & $04-512$ & 3 samples & $01-06$ & 2 samples & $02-146$ & 3 samples & $01-14$ & Absence \\
\hline E. coli & Absence & -- & 2 samples & 01- 02 & Absence & -- & 3 samples & $01-02$ & Absence \\
\hline Parasites & Absence & -- & Absence & -- & Absence & -- & Absence & -- & Absence \\
\hline Rainy season & $n=6$ & & $n=$ & & $n=6$ & & $n=3$ & & \\
\hline Heterotrophic bacteria & All samples & $240-1144$ & All samples & $18-360$ & All samples & $17-189$ & All samples & $51-308$ & $\begin{array}{c}<50.000 \\
\mathrm{CFU} / 100 \mathrm{~mL}\end{array}$ \\
\hline Total coliform & 6 samples & $02-348$ & 2 samples & $300-973$ & 3 samples & $04-280$ & 6 samples & 01- 69 & Absence \\
\hline E. coli & 4 samples & $02-07$ & 1 sample & 15 & 2 samples & $01-163$ & 4 samples & $02-33$ & Absence \\
\hline Parasites & Absence & -- & Absence & -- & Absence & -- & Absence & -- & Absence \\
\hline
\end{tabular}


The number of samples with E. coli was also higher during the rainy season, with 11 positive samples but just 5 during the dry period. The presence of E.coli in water samples from schools is in disagreement with the Brazilian standards for potability as delineated in the Decree 2914 (Brasil, 2011). E. coli is an excellent indicator of fecal contamination in water because it is a microorganism belonging to the intestinal microbiota of mammals and birds (Hunter, 2003). The origin of E.coli in water samples may be the same as that of the total coliforms, due to the proximity of the shallow well to the septic tank and the lack of adequate maintenance of the water tanks. The presence of these microorganisms in water suggests contact with fecal material and highlights the possibility that other fecal microorganisms could be present in the water (i.e., Cryptosporidium and hepatitis virus), indicating that the water is inadequate for human consumption and could cause health risks to school children, such as diarrhea, hepatitis and other gastric intestinal disturbances. More detailed research on this region also is recommended, since most studies in the Amazon region have been conducted to evaluate the presence of total coliforms and E.coli in surface waters such as rivers and streams (Aguiar et al., 2014; Azevedo, 2006).

\subsection{Physical chemical parameters and chemical composition of drinking water}

The mean, minimum and maximum values of some physicochemical parameters in water from schools are presented in Table 4. Drinking water at temperatures between $25-30^{\circ} \mathrm{C}$ was acidic with $\mathrm{pH}$ ranging from 4.2 to 5.2 at Schools $\mathrm{A}, \mathrm{B}$ and $\mathrm{C}$ and 4.7 to 5.0 at School D. The values found for $\mathrm{pH}$ in all schools are below the recommended minimum of 6.0. The low $\mathrm{pH}$ of local groundwater may result from natural processes, such as partial solubilisation of siliciclastic rocks (e.g., sandstone of the Alter do Chão formation). Alternative processes like pyrite oxidation or acid rain, commonly found in industrial areas (Edmunds and Smedley, 1996), are unlikely to occur in the region. Other studies have detected low groundwater $\mathrm{pH}$ (around 4.5 - 5.0) as a common feature in different places in the Amazon (Medeiros et al., 2016; Mendes et al., 2017).

The health effects of acidic water intake remain unclear. The WHO (2003) reported about skin and mucous irritation after exposure to acid water, but some gastric and intestinal disturbances are likely to occur. The acid drinking water may contribute to adverse health effects, since many minerals are soluble in acid water, thus releasing some toxic trace metals such as $\mathrm{Al}, \mathrm{Cd}$ and $\mathrm{Pb}$ (Edmunds and Smedley, 1996). The solubility of $\mathrm{Al}$ is strongly $\mathrm{pH}-$ dependent and significant environmental concentrations could be found below $\mathrm{pH} 5.5$, where increasing concentrations are related to the solubility of microcrystalline gibbsite (Bache, 1986).

Water turbidity was very low for all samples and yielded no great variations between the schools. Potable water normally registers turbidity up to 5.0 NTU (Brasil, 2011).

The highest water conductivity found in Schoolss A and C, with shallower wells, suggests a greater susceptibility to water contamination. There are no recommended values for conductivity in Brazilian legislation. Natural waters, in general, according the Environmental Company of the State of São Paulo (CETESB), show conductivity of 10 to $100 \mu \mathrm{S} \mathrm{cm}$ and the values increase in more-polluted waters when solid particles are added to water (CETESB, 2009). Tancredi (1996) showed conductivity ranging from 11 to $28 \mu \mathrm{S} \mathrm{cm}$ in groundwater from Santarém. These figures are similar to those found in School D and lower than those found in Schoolss A and C.

The alkalinity of water presented a wide variation among schools in the range of 3 to $40 \mathrm{mg} \mathrm{L}^{-1}$ of $\mathrm{CaCO}_{3}$. There is no recommendation for water alkalinity in Ordinance 2914; however, in general, water for human consumption should not exceed $120 \mathrm{mg} / \mathrm{L}$ of $\mathrm{CaCO}_{3}$. Below this limit, alkalinity has no sanitary significance, although at higher levels it can cause an unpleasant taste for consumers (CETESB, 2009). 
Table 4. Mean, Minimum (Min) and Maximum (Max) of some physicochemical parameters in drinking water from Schools A, B and C in Santarém and D in Mojuí dos Campos.

\begin{tabular}{|c|c|c|c|c|c|c|c|c|c|c|c|c|}
\hline \multirow{2}{*}{ Parameters } & \multicolumn{3}{|c|}{ School A } & \multicolumn{3}{|c|}{ School B } & \multicolumn{3}{|c|}{ School C } & \multicolumn{3}{|c|}{ School D } \\
\hline & Mean & Min & Max & Mean & Min & $\operatorname{Max}$ & Mean & Min & $\operatorname{Max}$ & Mean & Min & $\operatorname{Max}$ \\
\hline \multicolumn{13}{|c|}{ Dry season } \\
\hline pH & 4.2 & 3.8 & 4.8 & 4.6 & 4.3 & 5.0 & 4.5 & 4.0 & 5.0 & 5.0 & 4.3 & 5.8 \\
\hline Turbidity (NTU) & 0.2 & 0.1 & 0.5 & 0.5 & 0.4 & 0.6 & 0.1 & 0.1 & 0.2 & 0.6 & 0.2 & 1.5 \\
\hline $\begin{array}{l}\text { Conductivity } \\
(\mu \mathrm{S} \mathrm{cm})\end{array}$ & 99 & 88 & 131 & 57 & 32 & 81 & 67 & 22 & 126 & 27 & 16 & 59 \\
\hline $\begin{array}{l}\text { Alkalinity } \\
\left(\mathrm{mg} \mathrm{L}^{-1} \text { of } \mathrm{CaCO}_{3}\right)\end{array}$ & 13 & 10 & 18 & 06 & 04 & 10 & 04 & 03 & 07 & 13 & 07 & 20 \\
\hline
\end{tabular}

\begin{tabular}{lllllllllllll}
\hline \multicolumn{10}{c}{ Rainy season } \\
\hline $\mathrm{pH}$ & 4.3 & 4.1 & 4.8 & 5.2 & 4.6 & 6.0 & 4.6 & 4.0 & 5.4 & 4.7 & 4.4 & 4.9 \\
Turbidity (NTU) & 0.2 & 0.1 & 0.6 & 0.7 & 0.2 & 1.7 & 0.1 & 0.1 & 0.2 & 0.3 & 0.1 & 0.7 \\
$\begin{array}{l}\text { Conductivity } \\
(/ \mathrm{S} \mathrm{cm})\end{array}$ & 144 & 118 & 166 & 48 & 23 & 95 & 91 & 78 & 104 & 18 & 14 & 26 \\
$\begin{array}{l}\text { Alkalinity } \\
\left(\mathrm{mg} \mathrm{L}^{-1} \text { of } \mathrm{CaCO}_{3}\right)\end{array}$ & 08 & 03 & 11 & 30 & 15 & 40 & 24 & 13 & 35 & 11 & 10 & 12 \\
\hline
\end{tabular}

The mean, minimum and maximum concentrations of the most abundant anions in groundwater and the maximum value allowed by Brazilian Ordinance 2914 are shown in Table 5. Concentrations of $\mathrm{N}_{-} \mathrm{NO}_{2}{ }^{-}, \mathrm{PO}_{4}{ }^{3-}$ and $\mathrm{Br}^{-}$were below detection limits in all samples and were not registered in Table 5; the mean concentrations of $\mathrm{F}^{-}$were very low as well, but were included in the table. All anion concentrations were below the maximum limits of Ordinance 2914.

Table 5. Mean, Minimum (Min) and Maximum (Max) values of anions $\left(\mathrm{mg} \mathrm{L}^{-1}\right)$ in water samples from Schools A, B and C in Santarém and D in Mojuí dos Campos and the reference values $\left(\mathrm{mg} \mathrm{L}^{-1}\right)$ from Brazilian ordinance 2914.

\begin{tabular}{|c|c|c|c|c|c|c|c|c|c|c|c|c|}
\hline \multicolumn{3}{|c|}{ School A } & \multicolumn{3}{|c|}{ School B } & \multicolumn{3}{|c|}{ School C } & \multicolumn{3}{|c|}{ School D } & \multirow[t]{2}{*}{$\begin{array}{c}\text { Maximum limits } \\
\text { Ordinance } 2914\end{array}$} \\
\hline Mean & Min & Max & Mean & Min & Max & Mean & Min & $\operatorname{Max}$ & Mean & Min & $\operatorname{Max}$ & \\
\hline \multicolumn{13}{|c|}{ Dry season } \\
\hline 0.02 & 0.02 & 0.04 & LD & LD & LD & LD & LD & LD & 0.01 & 0.01 & 0.03 & 1.5 \\
\hline 11.2 & 11.1 & 11.4 & 1.8 & 1.7 & 2.2 & 4.0 & 1.3 & 9.2 & 2.0 & 2.0 & 2.0 & 250 \\
\hline 5.8 & 5.7 & 6.0 & 0.5 & 0.2 & 0.8 & 1.9 & 0.06 & 5.6 & 0.1 & 0.09 & 0.1 & 10 \\
\hline 6.8 & 6.7 & 7.2 & 0.3 & 0.1 & 0.6 & 0.2 & 0.1 & 0.4 & 0.75 & 0.7 & 0.8 & 250 \\
\hline \multicolumn{13}{|c|}{ Rainy season } \\
\hline 0.02 & 0.02 & 0.03 & LD & LD & LD & 0.03 & 0.03 & 0.05 & 0.01 & 0.01 & 0.04 & 1.5 \\
\hline 14.2 & 12.5 & 15.1 & 2.5 & 1.5 & 4.4 & 9.1 & 7.4 & 12.6 & 2.3 & 2.3 & 2.3 & 250 \\
\hline 8.0 & 7.1 & 8.7 & 0.3 & 0.04 & 0.8 & 5.4 & 4.3 & 7.4 & 0.1 & 0.1 & 0.2 & 10 \\
\hline 8.6 & 7.6 & 9.5 & 0.8 & 0.1 & 2.0 & 0.5 & 0.4 & 0.51 & 0.6 & 0.6 & 0.6 & 250 \\
\hline
\end{tabular}

$\mathrm{LD}=$ below detection limit.

The anion $\mathrm{Cl}^{-}$presented the greatest anion concentration in drinking water at all schools, in the range of 1.3 to $15.1 \mathrm{mg} \mathrm{L}^{-1}$, and $\mathrm{SO}_{4}{ }^{2-}$ yielded concentrations well below the recommended maximum. These findings are consistent with those reported by Tancredi (1996). $\mathrm{Cl}^{-}$and $\mathrm{SO}_{4}{ }^{2-}$ are widely distributed in the environment, including in waters, and no healthbased guideline value is proposed for chloride in drinking water (Tancredi, 1996).

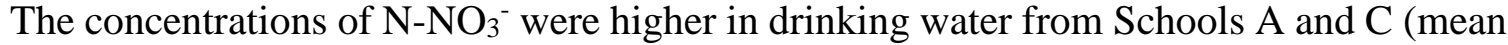
values 1.9 and $8.0 \mathrm{mg} \mathrm{L}^{-1}$ ) than at Schools $\mathrm{B}$ and $\mathrm{D}$ (mean values between 0.1 and $0.5 \mathrm{mg} \mathrm{L}^{-1}$ ) 
with deeper wells, and the highest concentrations were found in the rainy season. Contamination by $\mathrm{N}_{-} \mathrm{NO}_{3}{ }^{-}$in groundwater is possible due to deficient sanitation systems, based on increasing use of septic tanks in areas of high population density (Vanier et al., 2010). The proximity (less than $16 \mathrm{~m}$ ) between the wells and the septic tanks in Schools A and C may explain this finding. In the Santarém region, Tancredi (1996) found low values for $\mathrm{N}^{-\mathrm{NO}_{3}}{ }^{-}$up to $3.32 \mathrm{mg} \mathrm{L}^{-1}$ in groundwater. These values are greater than our results for drinking water from deep wells (Schools B and D) and lower than those found from shallow wells (Schools A and C). Medeiros et al. (2016) found high concentrations of $\mathrm{N}^{-\mathrm{NO}_{3}}{ }^{-}$in shallow wells $(7.7-61.35$ $\mathrm{mg} \mathrm{L}^{-1}$ ) in riparian communities that were exposed to domestic and industrial pollutants elsewhere in the Amazon region.

The toxicity of $\mathrm{N}^{-\mathrm{NO}_{3}}{ }^{-}$is mainly attributable to its reduction to nitrite in the human body and the major biological effect of nitrite is its involvement in the oxidation of normal Haemoglobin $(\mathrm{Hb})$ to methaHb (haematological disturbance), which is unable to transport oxygen to tissues (WHO, 2011). The $\mathrm{Hb}$ of infants is more susceptible to conversion to metHb and the reduced oxygen transport becomes clinically manifest; the condition, called "methemoglobinemia", causes cyanosis. In addition, nitrite was shown to react with nitrosatable compounds in the human stomach to form N-nitroso compounds, which have been demonstrated to be carcinogenic in tested animal species, although some of the most readily formed compounds, such as N-nitrosoproline, are not carcinogenic in humans (WHO, 2011).

Mean concentrations of trace elements as well as maximum and minimum contents in drinking water from the schools are shown in Table 6.

The concentrations of cations in the samples of Schools $\mathrm{A}$ and $\mathrm{C}$ were, in descending order, $\mathrm{Na}>\mathrm{Ca}>\mathrm{K}>\mathrm{Mg}>\mathrm{Al}$; and in the samples of Schools $\mathrm{B}$ and $\mathrm{D}$ the order was $\mathrm{Na}>\mathrm{K}>\mathrm{Ca}>\mathrm{Mg}>$ Al. Cations are commonly found in compounds in acceptable concentrations in the chemical constitution of natural waters (Edmunds and Smedley, 1996), and these elements are essential for human health, since they play important roles in cellular metabolism and physiology (Bowman et al., 2003). Water is an important source of these elements, and Ordinance 2914 does not set recommended maximum limits for $\mathrm{Ca}, \mathrm{K}$ and $\mathrm{Mg}$, but only for $\mathrm{Na}$ and $\mathrm{Al}$. The acceptable limit of $\mathrm{Na}$ in water is based on the taste it can confer, since water with high concentrations of $\mathrm{Na}$ becomes brackish and is not recommended for human consumption. The $\mathrm{Na}$ levels in the water samples are acceptable and at higher concentrations in Schools A and C. Similarly, concentrations of $\mathrm{Ca}, \mathrm{K}, \mathrm{Mg}$ and $\mathrm{Al}$ were higher in shallower well samples. The concentrations of these chemical compounds, with the exception of $\mathrm{Al}$, in schools with deep wells (B and D) were very similar to those found by Tancredi in 1996. The results suggest that the shallow wells of the schools were more susceptible to contamination by these elements and it is recommended to conduct periodic monitoring of the quality of drinking water in these schools.

The concentrations of trace elements are below the maximum limits recommended by the Ordinance 2914, except for Al at Schools A (414-672 $\mathrm{ng} \mathrm{ml}^{-1}$ ) and C (71-1370 $\mathrm{ng} \mathrm{ml}^{-1}$ ). The concentration of $\mathrm{Al}$ exceeded the recommended concentrations in all samples of School $\mathrm{A}$ and in four samples (out of the six analysed) of School C. The rather high concentration of $\mathrm{Al}$ in water samples from Schools A and C could be associated with natural process, i.e., interaction between water and rocks in the upper portion of the Alter do Chão geologic formation; moreover, when the $\mathrm{pH}$ value of the water is below 5.5, the chances of solubilization of $\mathrm{Al}$ in water increases substantially (Bache, 1986). Soils rich in organic matter and acids (pH below 5.5) also favor Al mobility and solubility, especially in areas with acidic rainfall and mining (Bache, 1986). 
Table 6. Mean, Minimum (Min) and Maximum (Max) concentrations of trace elements (ng $\mathrm{ml}^{-1}$ ) in drinking water from Schools $\mathrm{A}$, B, C and $\mathrm{D}$ in the Santarém region, State of Pará, Amazon and the maximum value allowed (ng ml-1) by Brazilian Ordinance 2914.

\begin{tabular}{|c|c|c|c|c|c|c|c|c|c|c|c|c|c|}
\hline \multirow{2}{*}{$\begin{array}{c}\text { Trace } \\
\text { elements }\end{array}$} & \multicolumn{3}{|c|}{ School A } & \multicolumn{3}{|c|}{ School B } & \multicolumn{3}{|c|}{ School C } & \multicolumn{3}{|c|}{ School D } & \multirow{2}{*}{$\begin{array}{l}\text { Maximum value Brazilian } \\
\text { Ordinance } 2914\end{array}$} \\
\hline & Mean & Min & Max & Mean & Min & Max & Mean & Min & Max & Mean & Min & Max & \\
\hline \multicolumn{14}{|c|}{ Dry season } \\
\hline $\mathrm{Al}$ & 429 & 414 & 429 & 92 & 32 & 184 & 510 & 71 & 1370 & 39 & 37 & 41 & 200 \\
\hline As & 0.04 & 0.02 & 0.06 & 0.008 & 0.008 & 0.02 & 0.01 & 0.01 & 0.04 & 0.01 & 0.01 & 0.02 & 10 \\
\hline B & 8.4 & 7.5 & 9.3 & LD & LD & LD & LD & LD & LD & LD & LD & LD & -- \\
\hline $\mathrm{Ba}$ & 6.6 & 6.1 & 7.4 & 33.8 & 31.8 & 36.2 & 21.4 & 13.6 & 26.0 & 19.1 & 18.5 & 19.4 & 700 \\
\hline $\mathrm{Ca}$ & 4271 & 4080 & 4387 & 234 & 158 & 383 & 1231 & 885 & 1691 & 130 & 121 & 153 & -- \\
\hline $\mathrm{Cd}$ & 0.004 & 0.002 & 0.007 & 0.01 & 0.01 & 0.02 & 0.007 & 0.004 & 0.01 & 0.02 & 0.02 & 0.01 & 5.0 \\
\hline $\mathrm{Cr}$ & 0.02 & 0.02 & 0.04 & 0.05 & 0.04 & 0.07 & 0.14 & 0.04 & 0.3 & 0.04 & 0.03 & 0.05 & 50 \\
\hline $\mathrm{Cu}$ & 6.1 & 4.8 & 7.6 & 32.2 & 24.6 & 58.0 & 1.9 & 1.5 & 2.2 & 9.3 & 2.8 & 27.1 & 2000 \\
\hline $\mathrm{Fe}$ & $L D$ & $L D$ & $L D$ & 8.3 & 6.2 & 11.5 & 9.6 & 8.0 & 12.0 & $L D$ & $L D$ & $L D$ & 300 \\
\hline $\mathrm{K}$ & 2177 & 2139 & 2217 & 1386 & 1333 & 1476 & 955 & 530 & 1778 & 144 & 138 & 152 & -- \\
\hline $\mathrm{Mg}$ & 593 & 585 & 612 & 172 & 150 & 207 & 564 & 469 & 679 & 116 & 115 & 119 & -- \\
\hline $\mathrm{Mn}$ & 10.8 & 10.5 & 11.0 & 5.5 & 5.0 & 6.4 & 7.9 & 6.2 & 11.2 & 4.2 & 4.01 & 4.2 & 100 \\
\hline $\mathrm{Na}$ & 1034 & 10440 & 10055 & 1225 & 860 & 1832 & 3733 & 970 & 9257 & 853 & 832 & 870 & 200000 \\
\hline $\mathrm{Ni}$ & 0.1 & 0.07 & 0.16 & 0.62 & 0.3 & 1.1 & 0.38 & 0.37 & 0.40 & LD & LD & LD & 70 \\
\hline $\mathrm{Pb}$ & 2.9 & 0.4 & 10 & 2.8 & 1.6 & 1.8 & 0.9 & 0.2 & 2.2 & 0.38 & 0.17 & 1.08 & 10 \\
\hline $\mathrm{Zn}$ & 11.3 & 9.68 & 16.89 & 50.5 & 18.4 & 93.7 & 4.3 & 3.2 & 5.7 & 11.1 & 6.9 & 23.3 & 5000 \\
\hline \multicolumn{14}{|c|}{ Rainy season } \\
\hline $\mathrm{Al}$ & 625.3 & 586 & 672 & 53.4 & 36.0 & 83.0 & 1045 & 868 & 1353 & 43 & 37 & 54 & 200 \\
\hline As & 0.07 & 0.05 & 0.1 & 0.01 & 0.01 & 0.02 & 0.1 & 0.06 & 0.2 & 0.02 & 0.02 & 0.05 & 10 \\
\hline B & 6.8 & 6.4 & 7.3 & 2.3 & 1.7 & 2.6 & 3.4 & 2.6 & 3.8 & $L D$ & $L D$ & $L D$ & -- \\
\hline $\mathrm{Ba}$ & 6.6 & 6.1 & 7.1 & 35.4 & 32.7 & 39.7 & 11.0 & 9.2 & 13.7 & 19.3 & 17.9 & 20.2 & 700 \\
\hline $\mathrm{Ca}$ & 5675 & 5395 & 6109 & 337 & 163 & 613 & 1579 & 1223 & 2240 & 156 & 146 & 178 & -- \\
\hline $\mathrm{Cd}$ & 0.013 & 0.008 & 0.01 & 0.02 & 0.01 & 0.03 & 0.03 & 0.01 & 0.04 & 0.006 & 0.003 & 0.006 & 5.0 \\
\hline $\mathrm{Cr}$ & 0.06 & 0.06 & 0.08 & 0.06 & 0.05 & 0.08 & 0.11 & 0.10 & 0.12 & 0.03 & 0.03 & 0.04 & 50 \\
\hline $\mathrm{Cu}$ & 6.9 & 6.02 & 7.8 & 67.4 & 23.8 & 137 & 5.0 & 2.1 & 10.1 & 9.3 & 4.27 & 14.8 & 2000 \\
\hline $\mathrm{Fe}$ & $L D$ & $L D$ & $L D$ & 5.0 & 4.1 & 6.3 & 4.2 & 2.5 & 6.9 & LD & LD & LD & 300 \\
\hline $\mathrm{K}$ & 2661 & 2585 & 2840 & 1530 & 1378 & 1458 & 1503 & 1190 & 1977 & 168 & 162 & 185 & -- \\
\hline $\mathrm{Mg}$ & 771 & 744 & 811 & 202 & 153 & 289 & 437 & 375 & 561 & 140 & 134 & 144 & -- \\
\hline $\mathrm{Mn}$ & 11.4 & 10.5 & 11.9 & 6.3 & 5.1 & 8.0 & 9.4 & 8.1 & 11.6 & 4.5 & 4.4 & 4.6 & 100 \\
\hline $\mathrm{Na}$ & 13087 & 12649 & 13817 & 1760 & 905 & 3456 & 8337 & 6400 & 11760 & 944 & 916 & 981 & 200000 \\
\hline $\mathrm{Ni}$ & 0.3 & 0.2 & 0.3 & 1.1 & 0.9 & 2.0 & 0.2 & 0.2 & 0.3 & 0.1 & 0.1 & 0.1 & 70 \\
\hline $\mathrm{Pb}$ & 0.74 & 0.55 & 1.1 & 5.4 & 1.8 & 9.5 & 5.9 & 3.2 & 9.6 & 0.3 & 0.29 & 0.34 & 10 \\
\hline $\mathrm{Zn}$ & 11.9 & 10.6 & 14.8 & 110 & 42.6 & 222 & 3.7 & 3.3 & 4.1 & 9.5 & 7.2 & 11.8 & 5000 \\
\hline
\end{tabular}

$\mathrm{LD}=$ below detection limit. 
According to the Agency for Toxic Substances and Disease Registry (ATSDR), neurological effects and Alzheimer's disease have been associated with oral exposure to Al, (ATSDR, 2008). Although there is evidence for this association, as proposed over 40 years ago, it is still controversial. Studies indicated a weak association between elevated intake doses of $\mathrm{Al}$ and increasing risk of neurological dysfunction and Alzheimer's disease (Walton, 2014). Alzheimer's disease is a human form of chronic Al neurotoxicity (Walton, 2014). However, according to ATSDR (2008), the absorption of Al is low through the human intestinal system, generally in the range of $0.1-0.4 \%$, and therefore oral exposure should be not be harmful. In children, the effects may be higher, especially in individuals with pathologies associated with the renal system. In these cases, bone damage may also occur, since excess Al may limit phosphate absorption, which is necessary for bone maintenance and is an important concern in growing children (ATSDR, 2008).

\subsection{Human health risk assessment}

Human health risk assessment associated with the ingestion of groundwater is important due to the increased demand for drinking water from the Alter do Chão aquifer in the Santarém region, and disorganized growth and lack of sound sanitary measures in the region could affect groundwater quality. With the values obtained from the environmental Daily Exposure and Reference Dose, we estimated the non-carcinogenic risks through the HQ and HI for each school during six months. Input values of exposure were assumed, aiming to quantify and indicate the contaminants as a priority for health in drinking water (Castilhos et al., 2014).

Table 7 shows the Hazard Quotient (HQ) for a number of metals and nitrate exposure through water consumption for children in schools and their respective Hazard Index (HI) (sum of the HQs). The non-carcinogenic risk associated with water intake in schools had a HI $>1$ for Schools A (2.84) and C (3.62). The drinking water in Schools B (0.48) and D (0.21) was considered safe according to the methodology adopted and does not show a risk for children. Aluminium presented HQ> 1 in Schools A and C and was the chemical compound that most contributed to the HI with $86.2 \%$ and $94.6 \%$, respectively. The second chemical element with the greatest contribution to the HI in Schools A and C was nitrate with $12.7 \%$ and $4.9 \%$, respectively. The values found for the non-carcinogenic daily exposure (DE) values for $\mathrm{As}, \mathrm{Cd}$ and $\mathrm{Cr}$ were less than $3.9 \times 10^{-6} \mathrm{mg} \mathrm{kg}$ day in schools due to the very low concentration of these elements in drinking water. Consequently, non-carcinogenic and carcinogenic risks were considered to be absent for these elements in the present study.

The methodology of health risk assessment has been used mainly due to exposure by contaminants from surface waters (USEPA, 1989; 1996), whereas groundwater is less frequently considered. In the Santarém region, to date, no reports of this type of methodology applied to chemical contaminants have been published. Castilhos et al. (2014) assessed the potential health risk to exposure groundwater for $\mathrm{Ni}, \mathrm{Hg}, \mathrm{Zn}, \mathrm{B}$ and $\mathrm{Ba}$ in 12 groundwater wells in urban area of the city Capitão Gervásio (Piauí State, northeast of Brazil), and found a noncarcinogenic risk $\mathrm{HQ}>1$ for $\mathrm{Ni}$. The presence of $\mathrm{Ni}$ in regional geology may have favoured the occurrence of hydrogeochemical anomalies or contamination from the soil in inadequate well constructions. Turdi and Yang (2016) assessed exposure to chemical contaminants through groundwater wells in four agricultural and pasture regions of China for children and adults and found more severe (carcinogenic and non-carcinogenic) risks for children. The authors found that non-carcinogenic risk was primarily associated with $\mathrm{Zn}$ and the carcinogenic risk was due to $\mathrm{Cr}$, As and $\mathrm{Cd}$. The hazard ratio was higher in agricultural areas, especially because of the high concentrations of As and $\mathrm{Cr}$ in the sampled wells.

The methodology mentioned above deals with the generation of numerical indices of critical areas and should be prioritized in public health and environmental control programs. The current results showed that groundwater of the most superficial layers of the Alter do Chão 
aquifer might be a matter of concern for local governments, especially for $\mathrm{Al}$ and nitrate contents.

Table 7. Hazard Quotient (HQ) due to oral exposure (ingestion) of some trace elements and nitrate in water in schools and the respective Hazard Index (HI).

\begin{tabular}{lcccc}
\hline & HQ School A & HQ School B & HQ School C & HQ School D \\
\hline $\mathrm{Al}$ & 2.45 & 0.33 & 3.40 & 0.19 \\
$\mathrm{~B}$ & 0.003 & 0.0004 & 0.0009 & 0.0003 \\
$\mathrm{Ba}$ & 0.002 & 0.010 & 0.007 & 0.008 \\
$\mathrm{Cu}$ & 0.013 & 0.10 & 0.007 & 0.01 \\
$\mathrm{Mn}$ & 0.006 & 0.003 & 0.005 & 0.002 \\
$\mathrm{Ni}$ & 0.0008 & 0.003 & 0.001 & 0.0004 \\
$\mathrm{Zn}$ & 0.006 & 0.02 & 0.001 & 0.002 \\
$\mathrm{~N}-\mathrm{Nitrato}$ & 0.36 & 0.02 & 0.20 & 0.005 \\
\hline HI & 2.84 & 0.48 & 3.62 & 0.21 \\
\hline
\end{tabular}

\section{CONCLUSIONS}

These results for drinking water quality from schools in Santarém and Mojuí dos Campos, Brazilian Amazon, allow us to make a series of conclusions and recommendations about how the quality of the water in this region should be managed.

The bacterial contamination (total coliforms and E. coli), especially during the rainy season of water samples from urban Schools (A and C), with shallower wells, show inconsistencies with the Brazilian Ordinance 2914 and expose school children to risks such as acute diarrheal diseases. Furthermore, the detection of E.coli in water samples from all schools indicates fecal contamination, suggesting that new microorganisms should be investigated such as hepatitis A virus and Cryptosporidium. The lack of maintenance and correct sealing of water tanks is a probable explanation for bacterial contamination in some water samples from wells of different depths in these schools. These results suggest that, to avoid these implications, schools should use chlorine-diluting pumps in their water supply systems, as well as establish a cleaning routine for the water tanks based on recommendations of the Brazilian Sanitary Surveillance Agency (ANVISA).

Determination of physicochemical parameters indicates that the water consumed in schools is acidic and confirmed results found in other studies in the Amazon region. The acid water may induce gastric and intestinal dysfunctions for school children, and favour the solubility of other toxic substances at the water source and along the course of groundwater. The chemical analyses showed low concentrations for most chemicals at levels below the recommended values in the Brazilian legislation. However, aluminium concentrations in water yielded values up to 5 times higher than the reference values of Ordinance 2914 in samples from schools with shallower wells in Santarém (Schools A and C). The prolonged exposure to high concentrations of aluminium in water may lead to some neurological implications, and in this case, the results of this study are preliminary, and it is suggested that future epidemiological studies are necessary in schools in the Santarém region, especially those with shallow wells. These future studies will serve to expand this debate and promote future interventions in the field of public and environmental health in this region. The acidic $\mathrm{pH}$ of the drinking waters and the presence of aluminium is probably related to natural processes of interaction between rock and water from the shallower layers of the aquifer system Alter do Chão. Nitrate concentrations in water yielded higher values in shallower well samples, up to 62 times higher than water from samples from deeper wells, and the presence of nitrate indicates a deficiency in sanitation that may lead to adverse implications for children's health, such as infant 
methemoglobinemia.

The evaluation of the health risk for children in schools, assessed through the ingestion of water, showed a non-carcinogenic risk only for schools with shallower wells located in Santarém. At these schools, the chemical compound that most contributed to risk was aluminium, followed by nitrate. In schools with deeper wells, the value of the hazard index remained below 1, evidencing the absence of risk for the evaluated elements. These results are preliminary for schools from the Santarém region, and they represent an important contribution to a necessary debate for future interventions in the field of public and environmental health in this region.

The current research shows unprecedented results related to the quality of groundwater from the Alter do Chão aquifer and its relation to human health in the region of Santarém. We emphasize the importance of implementation of control actions and monitoring of water quality, especially at localities where groundwater is collected from shallower wells that put the health of the population that use these waters at risk.

\section{ACKNOWLEDGEMENTS}

The research was supported by the Federal University of West Pará (UFOPA) and by the National Council of Technological and Scientific Development (CNPq) - Grant number 305119/2015-0. The assistance provided by Maria Aparecida Vendemiatto and Margareth Sugano from Geochemical Laboratory at the Institute of Geosciences of UNICAMP were fundamental in the construction of this work. The support provide by Gustavo Meschede (Laboratory LabVida) and Cátia Gonçalves, post-doctoral student, in water analysis were essential in the execution of this study. Thanks are also due to Jozinei Ferreira Lopes for the collaboration in the field work.

\section{REFERENCES}

AGENCY FOR TOXIC SUBSTANCES AND DISEASE REGISTRY - ATSDR. Toxicological profile for Aluminium. Atlanta: US department of health and human services, 2008.

AGUIAR, C. P. O.; PELEJA, J. R. P.; SOUSA, K. N. S. Qualidade da água em microbacias hidrográficas com agricultura nos municípios de Santarém e Belterra, Pará. Revista Árvore, v. 38, p. 983-992, 2014.

AZEVEDO, R. P. Uso da água subterrânea em sistema de abastecimento público de comunidades na várzea da Amazônia central. Acta Amazônica, v. 3, p. 313-320, 2006.

BACHE, B. W. Aluminium mobilisation in soils and waters. Journal of the Geological Society, v. 143, p.699-706, 1986.

BOWMAN, C. A.; BOBROWSKY, P. T.; SELINUS, O. Medical geology new relevance in the earth sciences. Episodes, Journal of International Geosciences, 2003.

BRASIL. Ministério da Saúde. Portaria N. 2.914, de 12 de Dezembro de 2011. Dispõe sobre os procedimentos de controle e vigilância da água para consumo e seu padrão de potabilidade. Diário Oficial [da] União, Brasília, DF, 14 de dezembro de 2011.

CASTILHOS, Z.; CESAR, R.; SIERPE, R.; FLORENCIO, J.; ARAUJO, P. Avaliação de risco à saúde humana associada ao consumo de águas subterrâneas contaminadas em Capitão Gervásio de Oliveira, Estado do Piauí. Geochimica Brasiliensis, v. 1, p. 13-22, 2014. http://dx.doi.org/10.21715/gb.v28i1.397 
COMPANHIA DE SANEAMENTO DO PARÁ- COSANPA. Companhia de Saneamento do Pará: Histórico. 2013. Disponível em http://www.cosanpa.pa.gov.br. Acesso em: 20 de Agosto de 2017.

EDMUNDS, W. M.; SMEDLEY, P. L. Groundwater geochemistry and health: an overview.

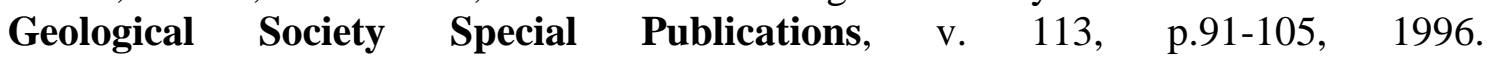
https://doi.org/10.1144/GSL.SP.1996.113.01.08

COMPANHIA AMBIENTAL DO ESTADO DE SÃO PAULO - CETESB. Qualidade das águas interiores no estado de São Paulo. 2009. Disponível em http://cetesb.sp.gov.br/aguas-interiores/wpcontent/uploads/sites/32/2013/11/variaveis.pdf. Acesso em: 20 setembro de 2017.

DAHUNSI, S. O.; OWAMAH, H. I.; AYANDIRAN, T. A.; ORANUSI, S. U. Drinking water quality and public health of selected towns in South Western Nigeria. Water Quality Exposure and Health, v. 6, p. 143-153, 2014. https://doi.org/10.1007/s12403-014-0118-6

FERREIRA, M. D.; ABREU, K. A.; FERREIRA, P. C.; ALVES, R. I. S; MUÑOZ, S. I. S. Parasites and prevalent bacteria in Monte Alegre Stream, located at the área of influence of the sanitary landfill of Ribeirão Preto. O mundo da saúde, v. 32, n. 3, p. 287-293, 2008 .

FUNDAÇÃO NACIONAL DE SAÚDE - FUNASA (Brasil). Manual prático de análise de água. Brasília, 2006. 147 p.

GOMES A. C. S.; COSTA, G. B.; VALE, R. S.; SANTANA, R. A. S.; BATALHA, S. S. A.; SILVA, J. T. et al. Micrometeorological index and children hospitalizations for respiratory diseases in Santarém Western Pará. Ciência e Natura, v. 38, p. 01-06, 2016.

HUNTER, P. R. Drinking water and diarrheal disease due to Escherichia coli. Journal of Water and Health, v. 1, n. 2, p. 65- 72, 2003. https://doi.org/10.2166/wh.2003.0008

INSTITUTO DE GeOgRAFIA E ESTATÍSTICA - IBGE. Population estimate of Pará State. 2016. Disponível em: http://cod.ibge.gov.br/2IAY2. Acesso em: 15 de julho de 2017.

INSTITUTO NACIONAL DE METEOROLOGIA - INMET. Dados da Rede do INMET. Banco de Dados Meteorológicos para Ensino e Pesquisa. Dados históricos - estação meteorológica de Santarém, dados mensais 2015-2016. Disponível em: http://www.inmet.gov.br/portal/index.php?r=bdmep/bdmep. Acesso: 20 March 2017.

JULIÃO, F. C. Avaliação das condições microbiológicas e físico químicas da água de reservatório domiciliar e predial: importância da qualidade dessa água no contexto da saúde pública. 2011. 157p. Tese (Doutorado). Escola de Enfermagem de Ribeirão Preto, Universidade de São Paulo, Ribeirão Preto, 2011.

KIM, K. N.; LEE, M. R.; CHOI, Y. H.; LEE, B. E.; HONG Y. C. Associations of blood cadmium levels with depression and lower handgrip strength in a community-dwelling elderly population: a repeated-measures panel study. The journals of gerontology. Series A, Biological sciences and medical sciences, v. 71, n. 11, p. 1525-1530, 2016. https://doi.org/10.1093/gerona/glw119

KÖPPEN, W. Das geographische System der Klimate. In: HANN, J. Von. Handbuch der Klimatologie. Berlin: Verlag von Gebrüder Borntraeger, 1936. p. 1-11. 
LAPWORTH, D. J.; DAS, P.; SHAW, A.; MURKHERJEE, A.; CIVIL, W.; PETERSEN, J. O. et al. Deep urban groundwater vulnerability in India revealed through the use of emerging organic contaminants and residence time tracers. Environmental Pollution, v. 240, p. 938-949, 2018. https://doi.org/10.1016/j.envpol.2018.04.053

LLOPIS-GONZÁLEZ, A.; SÁNCHEZ A. L.; REQUENA, P. M.; SUÁREZ-VARELA, M. M. Assessment of the Microbiological quality of groundwater in three regions of the Valencian Community (Spain). International Journal of Environmental Research and $\begin{array}{llllll}\text { Public Health, } & \text { v. 11, n. } & \text { p, }\end{array}$ http://dx.doi.org/10.3390/ijerph110505527

MAJUMDAR, D.; GUPTA, N. Nitrate pollution of groundwater and associated human health disorders. Indian Journal of Environmental Health, v. 42, n. 1, p. 28-39, 2000.

MEDEIROS, A. C.; LIMA, M. O.; GUIMARAES, R. M. Avaliação da qualidade da água de consumo por comunidades ribeirinhas em áreas de exposição a poluentes urbanos e industriais nos municípios de Abaetetuba e Barcarena no estado do Pará, Brasil. Ciência e saúde coletiva, v. 21, p. 695-708, 2016. https://doi.org/10.1590/141381232015213.26572015

MENDES, A.; GALVÃO, P.; SOUSA, J.; SILVA, I.; CARNEIRO, R. N. Relations of the groundwater quality and disorderly occupation in na Amazon low-income neighbourhood developed over a former dump area, Santarém-PA, Brazil. Environment, Development and Sustainability, p.1-16, 2017. https://doi.org/10.1007/s10668-017-0040-8

NALBANTCILAR, M. T.; PINARKARA, S. Y. Public health risk assessment of groundwater contamination in Batman, Turkey. Journal of Water and Health, v. 14, n. 4, p. 650-661, 2016.

NEVES, D. P. Human Parasitology. São Paulo: Atheneu, 2005. 501 p.

PALAMULENI, L.; AKOTH, M. Physico-Chemical and Microbial Analysis of Selected Borehole Water in Mahikeng, South Africa. International Journal of Environmental Research and Public Health, v. 12, n. 8, p .8619-8630, 2015. https://doi.org/10.3390/ijerph120808619

TANCREDI, F. N. S. Groundwater Resources of Santarém Fundamentals for use and protection. 1996. [PhD thesis]. Belém, PA: Universidade Federal do Pará, Belém, 1996.

TRATA BRASIL INSTITUTO. Organização da Sociedade Civil de Interesse Público. Ranking do Saneamento 2016. Disponível em http://www.tratabrasil.org.br/ranking-dosaneamento-4. Acesso em: 20 de novembro de 2017.

TURDI, M.; YANG, L. Trace Elements Contamination and Human Health Risk Assessment in Drinking Water from the Agricultural and Pastoral Areas of Bay County, Xinjiang, China. International Journal of Environmental Research and Public Health, v. 13, n.10, p. 938, 2016. http://dx.doi.org/10.3390/ijerph13100938

UNITED STATES. Environmental Protection Agency - USEPA. Office of Water. Risk Assessment Guidance for Superfund. vol I: Human Health Evaluation Manual. Washington, D.C, 1989.

UNITED STATES. Environmental Protection Agency - USEPA. Office of Water. Quantitative Uncertainty Analysis of Superfund Residential Risk Pathway Models for Soil and Groundwater: White Paper. OakRidge: Office of Health and Environmental Assessment, 1996. 
UNITED STATES. Environmental Protection Agency - USEPA. Office of Water. Integrated Risk Information System - IRIS. 2014. Disponível em: http://www.epa.gov.br/iris. Acesso em 20 de november de 2017.

UNITED STATES. Environmental Protection Agency - USEPA. Office of Water. Drinking Water from Household Wells. 2002. Disponível em: https://www.epa.gov/privatewells/drinking-water-household-wells. Acesso em: 25 Agosto de 2017.

WALTON, J. R. Chronic Aluminum Intake Causes Alzheimer's Disease: Applying Sir Austin Bradford Hill's Causality Criteria. Journal of Alzheimer's Disease, v. 40, p. 765-838, 2014. http://dx.doi.org/10.3233/JAD-132204

WORLD HEALTH ORGANIZATION - WHO. pH in Drinking-water. 2003. Disponível em: http://www.who.int/water_sanitation_health/dwq/chemicals/ph_revised_2007_clean_ve rsion.pdf. Acesso: 20 March 2017.

WORLD HEALTH ORGANIZATION - WHO. Protecting Groundwater for Health Managing the Quality of Drinking-water Sources. London: IWA Publishing, 2006.

WORLD HEALTH ORGANIZATION - WHO. Nitrate and nitrite in drinking-water. 2011. Disponível em: http://www.who.int/water_sanitation_health/dwq/chemicals/nitratenitrite2ndadd.pdf. Acesso: 21 August 2017.

WORLD HEALTH ORGANIZATION - WHO. Guidelines for Drinking-water quality: fourth edition incorporating the first addendum. 4rd ed. Geneva, 2017. 